No data on azinphosmethyl appeared in the 1978 report, so we omitted that year from our results.

Insecticide use dropped dramatically from 1982 through 1987, probably as a result of IPM research - cultural controls for the navel orangeworm developed by UC IPM, better monitoring of navel orangeworm and peach twig borer populations, and therefore better timing of insecticide applications and the reduced price per pound for almonds. Annual insecticide applications per thousand bearing acres of almond saveraged 786 pounds from 1982 through 1987, 45\% below the average of 1,430 pounds for the period 1979 through 1981. Assuming that a constant 360 pounds per thousand bearing acres were used primarily to control peach twig borer, the reduction in pounds used for navel orangeworm control would be $60 \%$.

Figure 3 shows the pesticide use information reported as a proportion of bearing acres treated. Pesticide use increased dramatically afterazinphosmethyl and carbaryl were registered for navel orangeworm on almonds. Approximately $21 \%$ of the total bearing almond acreage was treated annually between 1974 and 1976. The percentage of bearing almond acres that were treated peaked in 1981 at about $92 \%$, and with an average of about $77 \%$ from 1979 to 1981 .

The almond insect IPM program has resulted in an estimated $\$ 4.1$ million reduction in pesticidecosts. In the 1985 grower survey, $53 \%$ of growers reported spraying pesticides as part of their routineworm control practices as compared to $77 \%$ in the 1981 grower survey - a $24 \%$ reduction. We also know from the 1985 grower survey that those growers who sprayed used an average of 1.43 sprays per acre. The average bearing acreage between 1982 and 1988 was 387,000 acres. The $24 \%$ reduction in sprays has meant a reduction of 124,614 acre-sprays per year. At a cost of $\$ 32$ per spray, this has meant a direct savings in input costs to California almond growers of over $\$ 4$ million per year. This all adds up to an estimated benefit of $\$ 12.8$ million, including an increase of $\$ 8.7$ million in revenues resulting from increased salable production and a decrease of $\$ 4.1$ million in pesticide costs.

Additional benefits with less tangible economic values have accompanied the reduction in insecticide use: less risk of injury to the grower or farm workers, fewer secondary pest outbreaks (principally spider mites) resulting from disruption of the natural enemy complex, and less toxic wastewater and fewer empty pesticide cannisters needing disposal.

Karen Klonsky is Extension Economist, UC Davis; Frank G. Zalom is Director, IPM Implementation Group, UC Davis; and Bill Barnett is Area IPM Advisor, based at the Kearney Agricultural Center in Parlier.

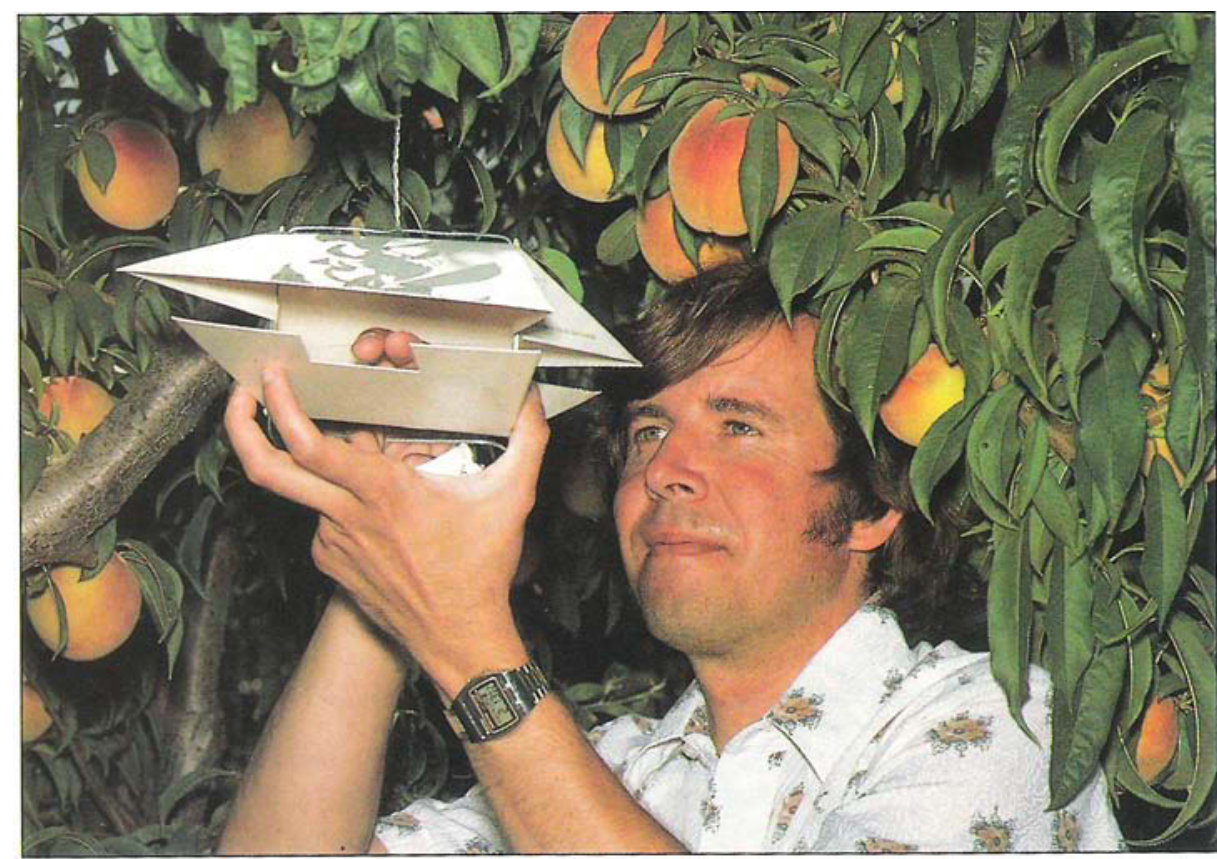

Frank Zalom, Director of the IPM Implementation Group, places a pheromone attractant into a codling moth trap. Moths drawn by the scent are caught on the trap's sticky inner surface.

\section{IPM Research results: Statewide IPM's first 10 years}

\author{
James I. Grieshop a Robert A. Pence
}

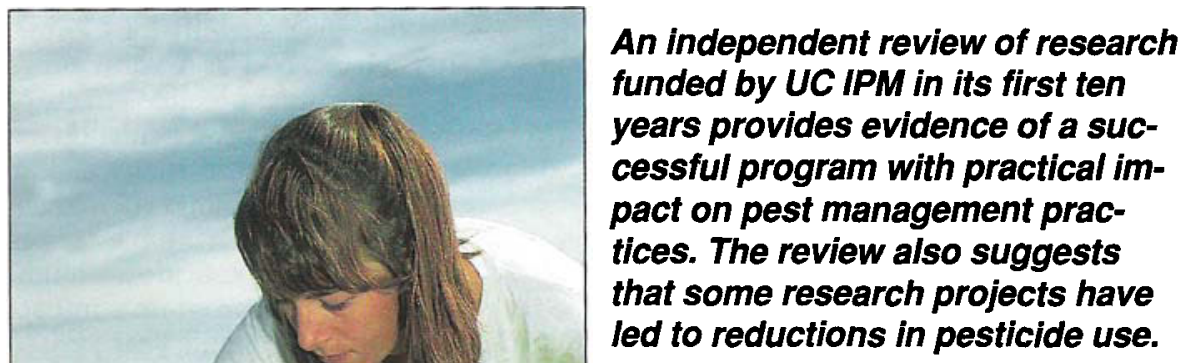

\begin{abstract}
An independent review of research funded by UC IPM in its first ten years provides evidence of a successful program with practical impact on pest management practices. The review also suggests led to reductions in pesticide use.
\end{abstract}

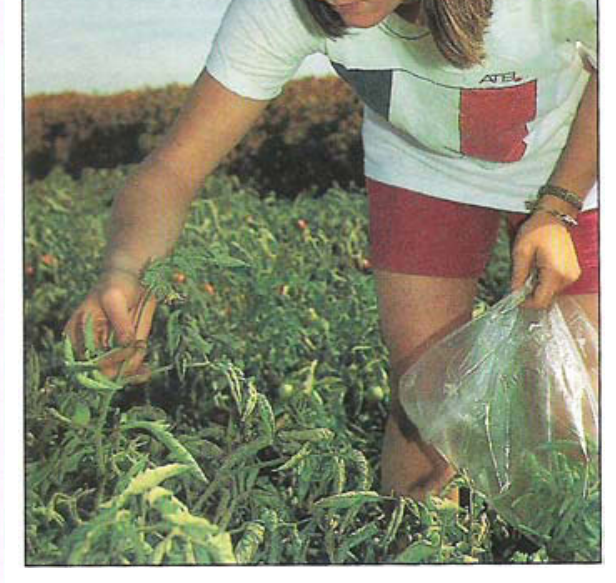

Sampling for tomato fruitworm (Heliothis zea) eggs in processing tomatoes. 
tives to pesticide use. The project also builds bridges between academic specialties (e.g., entomology, plant pathology, nematology, plant sciences, etc.) by supporting interdisciplinary research and development efforts that can lead to a more balanced approach to pest management. In ten years, the IPM Project has allocated over $\$ 7.1$ million, or $46 \%$ of its total budget, to 180 research projects.

The project's tenth anniversary is an appropriate time for evaluating its operation, accomplishments, and impacts. Ideally, such an evaluation would use multiple review and assessment methods to sketch an accurate portrait. As a first step in this evaluation, in 1989 we undertook an independent review of program-funded research. Our intent was toassess the program's effectiveness in promoting practical, interdisciplinary, goal-oriented research from the perspective of the researchers.

\section{Method}

Between 1979 and 1988,180 research projects received funding from the Statewide IPM Project. These projects were conducted by
229 principal investigators (PIs), so several projects must have been managed by multiple PIs. A number of researchers received funds for multiple projects. After we identified thePIs, we sent each a previously fieldtested questionnaire for each funded project. The original questionnaire was sent in August, 1989; if no completed survey was received within three weeks, we sent a reminder letter. A few PIs were contacted by telephone or in person for their response. The questionnaire requested specific information about the interdisciplinary nature of their research (Who assisted you in the research and implementation processes?); any useful products or information produced (Were any products such as databases, sampling equipment, sampling procedures, or nonchemical pest control measures developed through this research?); and field use of those results (Have the information or products developed in this research been used in-field by growers or pest control advisors?). We also requested information on published papers written as a result of a funded project, including journal and popular press articles.

TABLE 1. Distribution of IPM projects according to commodity group

\begin{tabular}{lrrrr}
\hline \hline Commodity & $\begin{array}{c}\text { Distribution among } \\
\text { all funded projects } \\
(\mathbf{n = 1 8 0 )}\end{array}$ & $\%$ & $\begin{array}{c}\text { Distribution among } \\
\text { projects in survey } \\
\text { response } \mathbf{( n = 1 6 2 )}\end{array}$ \\
\hline Grape & 29 & 16 & 20 & $\%$ \\
Citrus & 29 & 16 & 28 & 11 \\
Cotton & 25 & 13 & 20 & 16 \\
Tomato & 17 & 9 & 17 & 12 \\
Alfalfa & 17 & 9 & 18 & 18 \\
Almond & 9 & 5 & 9 & 5 \\
Rice & 6 & 3 & 7 & 4 \\
Cereal & 4 & 2 & 2 & 1 \\
Walnut & 4 & 2 & 4 & 2 \\
Other crops & 25 & 8 & 22 & 9 \\
Cross-commodity & 15 & & 15 & 9 \\
\hline
\end{tabular}

TABLE 2. Distribution of IPM projects according to the principal investigators' academic specialization

\begin{tabular}{lrrrr}
\hline \hline $\begin{array}{l}\text { Academic } \\
\text { specialization }\end{array}$ & \multicolumn{2}{c}{$\begin{array}{c}\text { Distribution among } \\
\text { all funded projects } \\
(\mathbf{n = 1 8 0 )}\end{array}$} & $\begin{array}{c}\text { Distribution among } \\
\text { projects in survey } \\
\text { response (n=159) }\end{array}$ \\
\hline Entomology & \multicolumn{2}{c}{$\%$} & & $\%$ \\
Plant pathology & 44 & 24 & 36 & 22 \\
Plant sciences & 21 & 11 & 15 & 9 \\
Nematology & 21 & 11 & 18 & 11 \\
Wildife biology & 11 & 6 & 15 & 9 \\
Interdisciplinary & 4 & 2 & 4 & 2 \\
Other & 70 & 38 & 64 & 40 \\
& 9 & 4 & 7 & 4 \\
\hline
\end{tabular}

TABLE 3. Distribution of IPM projects by principal investigators' intitutional affiliation

\begin{tabular}{|c|c|c|c|}
\hline Institution & $\begin{array}{l}\text { Distribution among } \\
\text { all funded projects } \\
(n=180)\end{array}$ & & $\begin{array}{l}\text { Ong } \\
\text { vey }\end{array}$ \\
\hline $\begin{array}{l}\text { Cross-institution* } \\
\text { UC Davis } \\
\text { UC Riverside } \\
\text { UC Berkeley } \\
\text { Cooperative Extension } \\
\text { Statewide IPM Project }\end{array}$ & $\begin{array}{r}\% \\
36 \\
26 \\
23 \\
7 \\
5 \\
1\end{array}$ & $\begin{array}{r}62 \\
43 \\
35 \\
12 \\
8 \\
1\end{array}$ & $\begin{array}{r}\% \\
38 \\
26 \\
21 \\
7 \\
4 \\
1\end{array}$ \\
\hline
\end{tabular}

- Signifies two or more University of California campuses or Cooperative Extension and one or more academic departments on the same campus.

\section{Response rates}

Wereceived completed, usablesurvey forms from $167(73 \%)$ of the 229 listed principal investigators. One hundred sixty-two, or $90 \%$ of all 180 funded projects were represented in those responses. Comparisons on the basis of commodity and academic specialty between the total number of funded proposals and those represented by at least one survey response indicated that individuals responding were representative of all PIs (tables 1, 2, and 3). Responses were compiled and tabulated by the authors, neither of whom was affiliated with the Statewide IPM Project.

Before 1986, IPM research efforts had emphasized a narrow commodity focus: alfalfa, citrus, tomatoes, cotton, rice, grapes, walnuts, and cereals. In 1986, the research emphasis was expanded to cut across commodity lines. Thereafter, research proposals were evaluated on the basis of pest management strategy: cultural controls, biological controls, monitoring systems, systems application, and commodity-pest interactions rather than on the basis of commodity. This changesubstantially increased therange of commodity-based projects as well as the number of cross-commodity projects funded by the program (table 1).

\section{Interdisciplinary bridges}

Most research projects (68\%) were managed by two or more researchers. Nearly two out of five projects involved researchers from two different agricultural disciplines (38\%) and two or more institutions (36\%) (tables 2 and 3). These results suggest, at least superficially, that the IPM Project was successful in fostering and generating interdisciplinary research. While the management of projects by investigators from different academic specializations may not guarantee the "ecological systems approach to pest management research" (as outlined in the 1979 IPM Annual Report), activities by interdisciplinary management teams suggest coordinationand cooperation across traditional research boundaries.

Researchers reported receiving assistance from a variety of sources. Most commonly, PIs were assisted by other university faculty, Cooperative ExtensionSpecialists, andFarm Advisors. Over half of allinvestigators $(51 \%)$ had Farm Advisors help them evaluate the practical usefulness of their proposed research, and $65 \%$ of the projects' investigators indicated that Farm Advisors helped them implement their results as field practice (table 4). Individual growers were reported as important contributors to IPM research. Growers provided field trial space for $58 \%$ of the projects, and evaluated one out of five projects (26\%) for practical utility. Organized commodity groups cooperated with researchers in $28 \%$ of all projects to help the investigators implement their research ac- 
TABLE 4. Number of projects receiving various types of assistance from various types of person (n $\mathrm{n}$ 150 , percentages are in parentheses)

\begin{tabular}{|c|c|c|c|c|c|c|c|c|c|}
\hline \multirow[b]{2}{*}{$\begin{array}{l}\text { Type of } \\
\text { assistance }\end{array}$} & \multicolumn{9}{|c|}{ Persons assisting } \\
\hline & $\begin{array}{l}\text { Individual } \\
\text { growers }\end{array}$ & PCAs & $\begin{array}{c}\text { Farm } \\
\text { advisors }\end{array}$ & $\begin{array}{c}\text { IPM } \\
\text { advisors }\end{array}$ & $\begin{array}{l}\text { Commodity } \\
\text { groups }\end{array}$ & $\underset{\text { faculty }}{\text { UC }}$ & $\begin{array}{c}\text { Cooperative } \\
\text { Extension } \\
\text { specialists }\end{array}$ & $\begin{array}{c}\text { IPM } \\
\text { project } \\
\text { staff }\end{array}$ & Other \\
\hline \multicolumn{10}{|l|}{$\begin{array}{l}\text { Developing } \\
\text { research }\end{array}$} \\
\hline $\begin{array}{l}\text { proposal } \\
\text { Evaluating } \\
\text { project }\end{array}$ & $25(16)$ & $19(12)$ & $68(45)$ & $36(24)$ & $25(16)$ & $112(74)$ & $77(51)$ & $28(18)$ & $20(13)$ \\
\hline $\begin{array}{l}\text { usefulness } \\
\text { Providing }\end{array}$ & $39(26)$ & $35(23)$ & $77(51)$ & $36(24)$ & $26(17)$ & $76(50)$ & $75(50)$ & $29(19)$ & $16(10)$ \\
\hline $\begin{array}{c}\text { space } \\
\text { Managing }\end{array}$ & $87(58)$ & $27(18)$ & $42(28)$ & $10(7)$ & $4(3)$ & $33(22)$ & $21(14)$ & $5 \quad(3)$ & $31(21)$ \\
\hline $\begin{array}{l}\text { field trial } \\
\text { Computer }\end{array}$ & $44(29)$ & $22(15)$ & $57(38)$ & $21(14)$ & $3(2)$ & $48(32)$ & $33(22)$ & $3(2)$ & $34(23)$ \\
\hline $\begin{array}{l}\text { assistance } \\
\text { Collecting }\end{array}$ & $O(0)$ & $0(0)$ & $10(7)$ & $8(5)$ & $1(1)$ & $55(36)$ & $21(14)$ & $39(26)$ & $21(14)$ \\
\hline data & $22(15)$ & $23(15)$ & $63(42)$ & $24(16)$ & $8(5)$ & $57(38)$ & $39(26)$ & $10(7)$ & $40(26)$ \\
\hline Other & $1(1)$ & $1(1)$ & $2(1)$ & $2(1)$ & $4(3)$ & $4(3)$ & $4(3)$ & 2 (1) & $7(5)$ \\
\hline
\end{tabular}

tivities. According to these findings, most funded proposals were researched and implemented with interdisciplinary and multi-level approaches that went beyond the specializations of the principal investigators.

\section{Research outcomes}

The IPM research projects have generated "products" to be used for pest management. These products include in-field pest managementstrategies, monitoring systems, and equipment. They also include publications of various types to disseminate researchbased pest management information.

Ninety-one percent of reporting projects claimed to have developed identifiable products. Products ranged from improved nonchemical pest control procedures to improved sampling methods, and from more effective decision-making procedures (e.g., action thresholds) to new pest monitoring equipment (table5). In all, PI responses indicated that 148 of the 162 projects led to development of one or more products, a result that suggests the UC IPM goal for "practical, goal-oriented research" 'was addressed and probably achieved.

More than 75\% (125) of the projects resulted in some type of publication, including 104 refereed journal articles. Other publications included popular press articles, Cooperative Extension publications, and book chapters. As of the end of 1989, 578 publications based on project-funded research had been produced.

Principal investigators also reported that such products as sampling and pest control procedures were in use in the field. Based on PI responses, about $43 \%$ of the funded research resulted in pestmanagement products or information that is now being used by growers and pest control advisers (PCAs) (table 6). Besides field application, funded research has reportedly led to further pest managementstudies and research $(54 \%)$ and to subsequent non-program funding for continued research (32\%).

\section{Effect on pesticide use}

Animportantquestion was whether research had contributed to the IPM goal of reducing the agricultural use of pesticides. Principal investigators were asked if they had any evidence that their research had resulted in

TABLE 5. Productivity of IPM research projects

\begin{tabular}{|c|c|c|}
\hline \multirow[t]{2}{*}{ Product } & \multicolumn{2}{|c|}{$\begin{array}{l}\text { Projects that have } \\
\text { generated the product }\end{array}$} \\
\hline & & $\%$ \\
\hline $\begin{array}{l}\text { Published papers } \\
\text { Refereed journal }\end{array}$ & 138 & 77 \\
\hline papers & 104 & 58 \\
\hline $\begin{array}{l}\text { Databases } \\
\text { Decision-making }\end{array}$ & 61 & 39 \\
\hline $\begin{array}{l}\text { procedures } \\
\text { Nonchemical pest }\end{array}$ & 59 & 37 \\
\hline control procedures & 56 & 35 \\
\hline Sampling procedures & 49 & 31 \\
\hline $\begin{array}{l}\text { Computer programs } \\
\text { Chemical pest }\end{array}$ & 31 & 19 \\
\hline control procedures & 21 & 13 \\
\hline Equipment & 12 & 8 \\
\hline
\end{tabular}

TABLE 6. Utilization of the products of IPM research

\begin{tabular}{lcc}
\hline \hline Product use & \multicolumn{2}{c}{ Projects whose } \\
products were so used
\end{tabular}

TABLE 7. Effect of IPM research on pesticide use,

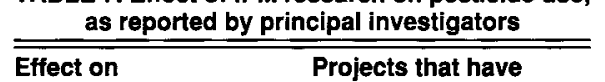
\begin{tabular}{ll}
$\begin{array}{l}\text { Effect on } \\
\text { pesticide use }\end{array}$ & $\begin{array}{r}\text { Projects that hav } \\
\text { had the effect }\end{array}$ \\
\hline
\end{tabular}

\begin{tabular}{llc} 
& & $\%$ \\
Reduction & 57 & 36 \\
No effect & 37 & 23 \\
Unknown & 48 & 30 \\
Research still in progress & 15 & 9 \\
\hline
\end{tabular}

a reduction in pesticide use. Thirty-six percent of all projects' PIs responded that they did have evidence of such pesticide reduction (table 7). In the questionnaire, we made no effort to document the nature or the validity of evidence, and the respondents' claims have not been verified. This result is intriguing and potentially significant. Moreover, it provides great incentive for the detailed study of the projects claiming to have reduced the use of chemical pesticides.

\section{Discussion}

This study gives important but preliminary evidence that the research efforts of the UC IPM program have led to numerous and significant results. Taken together, the responses of the PIs validate the effectiveness of a research grant allocation program that has succeeded in facilitating applied, problem-solving research. Funded proposals have resulted in many usable and used products. In a surprisingly large number of cases, IPM research may have led to reductions in pesticide use. The research program has led to the development of pest management information, equipment, and procedures that have been applied in the field, of publications, and of continued research activities. The research program has also involved Cooperative Extension Farm Advisors, growers, commodity groups, and pest control advisers in organized research activities.

Our conclusions are preliminary. Since our means for collecting information were limited to the questionnaire and our review of IPM Annual Reports, results have to be dealt with carefully. The validity of PI responses is an open question. This study also raises many questions that merit further investigation. For example: What is the connection between Farm Advisor or PCA involvement and the nature of in-field pest management practices? What evidence is there to indicate that pesticide reductions result from IPM research? To what degree are research-based "products" actually used, and how wide-spread is their use? Are products developed 10 years ago in wider use today than those developed 5 years ago? These are among the questions that can be included in future studies.

Nevertheless, the results of this review should help UC IPM staff and advisory committees evaluate their effectiveness in supporting research that meets the project's original mandates. The results can also be used to modify the grant allocation process by identifying research proposals that are most likely to meet project emphasis on rapid, practical field implementation.

James I. Grieshop is Community Education Specialist, and Robert A. Pence is Research Assistant, Applied Behavioral Sciences Department, UC Davis. 